\title{
Attitude to Risk of Credit Managers and Efficiency of Credit Management in Real Estate Investment Trusts in Kenya
}

\author{
Elodie Cyrielle Tchouadep \\ MBA Student \\ School of Graduate Studies \\ Catholic University of Eastern Africa \\ Kenya \\ Henry Kimani Mburu \\ Senior Lecturer of Accounting \\ School of Graduate Studies \\ Catholic University of Eastern Africa \\ Kenya \\ Thomas Githui \\ Lecturer of Accounting \& Finance \\ School of Graduate Studies \\ Catholic University of Eastern Africa \\ Kenya
}

\begin{abstract}
Risk attitude is one of the most important behaviors of managers in any company that affects decisions regarding consumption, saving and investing. Credit management on the other hand, is necessary in real estate organizations to ensure financial stability and business continuity. This study sought to examine the association between attitude to risk of credit managers and the efficiency of credit management in real estate investment trusts operating in Kenya. The study found out that $71.9 \%$ of credit managers are risk-averse while $28.1 \%$ are risk seekers. The study evidenced that risk seeking credit managers are associated with lower credit management efficiency. This result has implications for credit management practice; vetting of credit managers is essential because of their attitude to risk. This could improve the efficiency of credit management operations.
\end{abstract}

Keywords: risk attitude, credit management, real estate investment trusts

\section{Introduction}

\subsection{Background of the study}

Credit management is a function performed within a company aimed at improving and controlling credit policies that will lead to increased revenues and lower financial risks. Increasing collections, reducing credit costs, extending more credit to creditworthy customers, and developing competitive credit terms help enhance credit management efficiency (Greijmans, 2013). Timely identification of potential credit default is important as high default rates lead to decreased cash flows, lower liquidity levels, and financial distress. In this regard, efficiency of credit management is important to a company's cash flow as it determines the company's profitability. Efficient credit management requires a good credit policy that will incorporate competitive credit terms. Credit monitoring and control is also essential to help prevent events of distressed customers' repayment. Payne (2015) also suggests that adequate and objective credit analysis, through credit scoring is required in order to ensure that credit worthy applicants are extended credit. In ensuring that credit control operations are efficient; credit managers are involved in credit decisions. Credit managers have the duty of minimizing the credit risk exposure of the firm when conducting business (Perez, 2014). Simkovic (2016) defines credit risk as the risk of default on a debt that may arise from a borrower failing to make the expected repayment as per agreed terms of any contract with the firm; hence, it is a major cause of companies' failures in today's business environment. 
According to Ingram and Thompson (2012), the prevailing opinion of managers about risk is never identical because firms and individual managers have different risk attitudes. In this regard, risk taking credit managers will tend to take more risk when extending credit to customers in expectation of high returns compared to riskaverse credit managers. Due to the risk inherent in real estate activities, it is necessary for credit managers to make sound credit decisions, benchmark and implement up to date practices that will keep the company's exposure at an acceptable level, hence, enhance the profitability of the firm.

\subsection{Statement of the Problem}

Kani (2017) documents that the major cause of poor financial performance of firms is credit quality, hence, efficiency of credit management is required in order to enhance the profitability and financial stability of the firm. According to Murithi, Waweru and Muturi, (2016) credit risk has a significant negative effect on the financial performance of banks and other organizations in Kenya in both the short and long run. Delays in collecting cash from debtors as they fall due cause serious liquidity problems, increase bad debts, and affect customer relations of firms; hence, it is critical for firms to ensure credit operations are efficient in order to enhance profitability and secure the continuity of business operations. Managers' individual risk attitude on the other hand, influences the decisions they make in a firm (Paraschiv \& Shyti, 2017). Dar and Hakeem (2015) evidenced that psychological, perceived risk behavior and market factors positively affect the decisions made by managers. This compels credit managers to keep the firm's credit risk exposure at minimum when extending credit to clients. Despite the implementation of proven credit management practices, real estate investment trusts in Kenya are still incurring losses emanating from high default levels reported from customers. Few studies exist in developing countries, about the relationship between attitude to risk of credit managers and the efficiency of credit management; therefore, there is a need of empirical studies on the same.

\subsection{Research question}

What is the relationship between the attitude to risk of credit managers and the efficiency of credit management in real estate investment trusts in Kenya?

\subsection{Research Hypothesis}

Risk seeking credit managers are associated with higher credit management efficiency.

\section{Literature Review}

\subsection{Risk seeking attitude of credit managers}

Kusev, Purser, Heilman, Cooke, Schaik and Baranova (2017) point out that most managers make business decisions based on their individual risk behavior. A risk-taking manager will take a greater degree of financial risk when extending credit to customers in expectation of higher returns in the future. Nevertheless, the risk-taking manager will tend to tackle uncertainty using his or her skills and abilities in the hope of greater achievement (Zinn, 2017).

\subsection{Risk tolerant attitude of credit managers}

Risk tolerance is the degree to which an individual can take the risk inherent in a specific investment (Grable, 2017). This means that credit managers having a high degree of risk tolerance will mostly express a risk seeking behavior while those with a less degree of risk tolerance will express a risk aversion behavior. Mercadante (2012) also indicates factors such as the age, income stability, overall financial strength, portfolio size and temperament will influence risk tolerance among individuals.

\subsection{Risk-averse attitude of credit managers}

Satti (2013) argues that an individual tends to be risk-averse in choices involving sure gains and to be risk seeking in choices involving sure losses. This implies that risk-averse individuals avoid making riskier credit decisions by overvaluing the probability of loss relative to the probability of gain. According to (Kolakowski, 2017).experience, especially the economic environment affect the decisions of risk averse individuals. Credit managers, therefore, will adopt different stances on how risk-averse they feel about a proposed credit request given their experience, market conditions and risk appetite of the firm.

\subsection{Risk neutral attitude of credit managers}

A risk-neutral credit manager makes a credit decision by focusing on the single value that represents the credit instead of the range of the outcomes that may emerge from it. 
Figlewski (2016) indicates that a risk neutral individual will make a decision after having thought abstractly and creatively while envisaging possibilities. Consequently, the degree of uncertainty in a set of expected returns does not affect the credit decisions of risk neutral managers (Dohmen et al., 2011).

\subsection{Credit policy}

A credit policy is the guide for communication between the company and its customers (Bullivant, 2012). This means that a credit policy sets the terms and conditions for extending credit, customer qualification criteria, procedure for making collections and steps to be taken in case of customer delinquency. The major cause of liquidity and inadequate working capital problems in companies is the lack of credit standards and inappropriate credit policies (Alshatti, 2015). Moss (2013) points out that variables included in a credit policy should enable the firm determine the average period for debt collection and the proportion of bad debt losses.

\subsection{Credit Analysis}

Simkovic \& Kaminetzky (2010) state that credit analysis involves a wide variety of financial techniques aimed at assigning a risk rating of the proposed credit. This means that the credit worthiness of a credit applicant is determined having looked at the terms and conditions of the firm including the applicant's request. To ensure that credit management is efficient, the separation of the credit review function from the credit analysis, credit execution, and credit administration functions is essential (Edu, Bassey, \&Okpoho, 2018). In doing so, the credit review effort will be directed towards reducing credit risk as well as monitoring the performance of existing debt, handling bad debtors and recovering from failed debtors..

\subsection{Credit Monitoring and Control}

A credit control framework for handling credit deals and money accumulation as part of a credit function helps detect early signs of debt repayment problem that may arise in the course of business. This means that an independent division tasked with monitoring and controlling credit is critical within the organization in order to ensure a timely repayment of amounts due by debtors (Mutua, 2015). According to Yang, Wenchum and Jiaojiao (2017) credit monitoring and control aims at continuously auditing account receivables and debtors records. This implies that firms should assess whether clients are repaying debts as per the agreed credit terms using effective and efficient collection techniques and tools

\section{Research Design and Methodology}

\subsection{Research Methodology}

The study adopted a descriptive survey design. This method was adequate because it allowed for the collection of large amount of data from a sizable population in a highly economical way (Cooper \& Schindler, 2014).

\subsection{Study population and sampling}

The study conducted a census of 22 credit managers working for the eight licensed real estate investment trusts in Kenya. The study targeted one manager from the 22 managers for response. Moreover, the study extracted data from published annual reports for the period going 2002 to 2016 to derive indicators of credit management efficiency.

\subsection{Data Collection Sources}

The study used questionnaires to collect data on attitude to risk of credit managers. The survey measured the attitude to risk of credit managers using a tested domain specific risk attitude scale (Weber (2002). questionnaires were administered to credit managers through email method. Data extracted from published annual reports of the eight licensed real estate investment trusts in Kenya helped gain insight into figures that derived the ratio of bad debt to sales, the ratio of account receivables to sales income and the percentage of default on financial obligations from customers. These three indicators measured credit management efficiency as follows:

$\mathrm{BDS}_{\mathrm{i}, \mathrm{t}}=\mathrm{X}_{1 \mathrm{i}, \mathrm{t}} / \mathrm{X}_{2 \mathrm{i}, \mathrm{t}}$. Where: $\mathrm{Y}=$ bad debt to sales ratio (BDS), $\mathrm{X}_{1}$ - Bad debt written off, $\mathrm{X}_{2}$ - Operating income

$\mathrm{DSR}_{\mathrm{i}, \mathrm{t}}=\mathrm{X}_{1 \mathrm{i}, \mathrm{t} /}\left(\mathrm{X}_{2 \mathrm{i}, \mathrm{t}} / 360\right.$ days). Where: $\mathrm{Y}=$ day's sales in account receivable ratio (DSR), $\mathrm{X}_{1}$ - Account receivable, $\mathrm{X}_{2}$ - Operating income

$\mathrm{DR}_{\mathrm{i}, \mathrm{t}}=\mathrm{X}_{1 \mathrm{i}, \mathrm{t}} / \mathrm{X}_{2 \mathrm{i}, \mathrm{t}}$. Where: $\mathrm{Y}=$ default rate (DR), $\mathrm{X}_{1}$ - Amount of default, $\mathrm{X}_{2}$ - Account receivable

\subsection{Data Analysis}

Responses gathered from questionnaires on the likelihood of engaging in risk related activities were assigned scores (5- very likely, 4- likely, 3- not sure agree, 2- unlikely and 1- very unlikely). 
The study extracted one factor score to proxy for the attitude to risk of credit managers using. Principal component analysis. The study measured credit management efficiency using the ratio of bad debt to sales, ratio of account receivables to sales income and the percentage of default on financial obligations from customers. The study also performed Pearson correlation analysis to determine the relationship between attitude to risk of credit managers and credit management efficiency. A multiple regression model was used to test the hypotheses of the combined effect of the six independent variables (attitude to risk of credit managers, company's age, debtor turnover ratio, total asset, profit, work experience, professional qualification and financial year) on the dependent variable (efficiency of credit management) respectively. The study was guided by the following regression model: EFFCREDIT $_{i, t}=\beta_{0}+\beta_{1}$ RSKATT $_{i, t}+\beta 2$ AGE $_{i, t}+\beta 3$ DEBT $_{i, t}+\beta 4$ TA $_{i, t}+\beta 5$ PFT $_{i, t}+\beta 6$ EXP $_{i, t}+\beta 7$ PQ $_{i, t}+\beta 8$ $\mathrm{YEAR}_{\mathrm{i}, \mathrm{\varepsilon}}$ The variables are defined as follows;

Attitude to risk of credit managers (RSKATT ${ }_{i, t}$ ) was expected to impact positively the ratio of bad debt to sales, the ratio of account receivables to sales income and default rate This is because default levels are more likely to increase when credit managers become more risk taking in extending credit to customers. Company's age $\left(\mathrm{AGE}_{\mathrm{i}, \mathrm{t}}\right)$ was expected to impact positively on the ratio of bad debt to sales, the ratio of account receivables to sales income and default rate respectively. Due to the size of operations, existing companies will tend to have higher levels of defaults compared to new entrants. Debtor turnover ratio $\left(\mathrm{DEBT}_{\mathrm{i}, \mathrm{t}}\right)$ was expected to show a negative sign on the ratio of bad debt to sales, the ratio of account receivables to sales income and default rate . High levels of debt collection indicate a reduction in default levels. Total assets $\left(\mathrm{TA}_{\mathrm{i}, \mathrm{t}}\right)$, was expected to show a positive sign on the ratio of account receivables to sales income and a negative sign on both ratio of bad debt to sales and default rate. Given the size of total assets, large companies will tend to report high levels of receivables as compared to small companies. Profit $\left(\mathrm{PFT}_{\mathrm{i}, \mathrm{t}}\right)$ is expected to show a negative sign on both ratio of bad debt to sales and default rate while the ratio of accounts receivables to sales income is expected to show a positive sign. When profits rise, defaults levels decrease and receivables increase due to new credits extended to customers. Work experience $\left(\mathrm{EXP}_{\mathrm{i}, \mathrm{t}}\right)$ in credit management is expected to be negative on the ratio of bad debt to sales and default rate respectively while positive on the ratio of account receivables to sales income. This is because credit managers strive towards mitigating events defaults and reporting high levels of collections in the course of duty. Professional qualification $\left(\mathrm{PQ}_{\mathrm{i}, \mathrm{t}}\right)$ is expected to be negative on the ratio of bad debt to sales and default rate respectively while positive on the ratio of account receivables to sales income. Credit managers employ the professional skills they hold to effectively manage debtors and mitigate events of defaults. The financial year $\left(\mathrm{YEAR}_{\mathrm{i}, \mathrm{t}}\right)$ employed in the model as a dummy variable is expected to impact negatively the ratio of bad debt to sales, the ratio of account receivables to sales income and default rate. Companies strive towards increased collection and low defaults each year. All data were analyzed using descriptive and inferential statistics using the Statistical Package for the Social Sciences (SPSS) software package. The study presented findings using tables and percentages with the aim of summarizing responses and facilitating comparison.

\section{Results and Interpretation}

\subsection{Attitude to risk of credit managers}

The study employed principal components analysis to extract one factor score underlying the attitude to risk of credit managers. Higher scores indicated greater attitude to risk. The extracted factor score explained $49 \%$ of the variance for the entire set of variables. All items contributed to the factor structure and had a minimum primary factor loading of 0.4 or above (Table1). This may indicate that one clear pattern of response among respondents was identified. The values of total score below and above the mean score enabled the classification of credit managers as risk takers and risk- averse. From the findings, (41\%) of credit managers were risk-averse while $(16 \%)$ were risk seekers and neutrality were not observed.

\subsection{Efficiency of credit management}

Result from table 2 show default rate with an average of $54.79 \%$ and a standard deviation of 26.16. This gives an overview of the level of clients' defaults among real estate investment trusts in Kenya. A high level of customers' defaults reported with a significant variation between institutions. According to the table, bad debt to sales ratio varies from one to 37.49 with an average of $46.60 \%$ and a standard deviation of 37.49 . These figures show the real estate investment trusts' ability to manage credit risk. Day's sales in account receivable ratio show a high volatility in the provision of credit terms among real estate investment trusts in Kenya. 
The ratio varies from 16 to 1430 with an average of 408.21 and a standard deviation of 326.8. This confirms that real estate investment trusts in Kenya extend longer credit terms to customers.

\subsection{Relationship between attitude to risk of credit managers and efficiency of credit management}

\subsubsection{Correlation Analysis}

From the findings (table 3), bad debt to sales ratio was positively correlated with attitude to risk of credit managers and significant at 5\% significance level. This implies that the level of bad debts increases as credit managers are risk taking in extending credit to customers. Day's sale in account receivable ratio correlated positively and significantly with attitude to risk of credit managers at $1 \%$ significance level. This means that risktaking managers extend longer credit to clients compared to risk-averse managers among real estate investment trusts in Kenya. Furthermore, the correlation between default rate and attitude to risk of credit managers was positive and significant at the 5\% significance level. This indicates that the level of defaults increases as credit managers are risk taking in extending credits to clients. Bad debt to sales ratio correlated positively with day's sale in account receivables ratio and was significant at $1 \%$ significance level. This indicates that the probability of bad debts increases when credit managers extend longer credit terms to customers. The study expects this finding because it takes long to recover payments from clients who default on their financial obligations. The correlation between bad debt to sales ratio and default rate was also positive and significant at $5 \%$. This suggests that the probability of bad debt increases when clients default on financial obligations. This implies that the uncollectible amount of debt written off emanates from outstanding amounts due from clients to the organization. Lastly, day's sale in account receivable ratio correlated positively and significantly with default rate at 5\% significance level. This indicates that longer credit repayment terms increase the probability of defaults from clients in an organization. The study expects this finding because there is a low probability of default over a short credit period compared to an extended one.

\subsubsection{Regression Analysis}

\subsubsection{Bad debt to sales ratio}

Results from table 4 show the adjusted $\left(\mathrm{R}^{2)}\right.$ statistics of the analysis to be approximately $98.6 \%$ (percent). The estimated probability value (F-statistics) is highly significant $(0.000<0.01)$. The study concluded that risk taking credit managers are associated with lower credit management efficiency in real estate investment trusts in Kenya. This implies that firms report high levels of defaults when credit manager are risk taking in extending credit to clients.

\subsubsection{Day's sale in account receivable ratio}

Results from table 4 show the adjusted $\left(\mathrm{R}^{2)}\right.$ statistics has shown to be approximately $64.8 \%$ and the estimated probability value (F-statistics) is highly significant $(0.003<0.01)$. The study evidenced that risk taking credit managers are associated with lower credit management efficiency in real estate investment trusts in Kenya. This means that firms report low debt collection levels when credit manager become risk taking in extending longer credit terms to clients.

\subsubsection{Default rate}

Results from table 4 show the adjusted $\left(\mathrm{R}^{2)}\right.$ statistics has shown to be approximately $99.3 \%$ and the estimated probability value (F-statistics) is highly significant $(0.000<0.01)$. The study concluded that risk taking credit managers are associated with lower credit management efficiency in real estate investment trusts in Kenya. This indicates that firms report high levels of defaults when credit manager are risk taking in extending credit to clients.

\subsection{Hypothesis testing}

The null hypothesis of the study was as follows: Ho: Risk seeking credit managers are associated with higher credit management efficiency. From the results of the regression analysis (table 4), the study can reject the null hypothesis and conclude that risk seeking credit managers are associated with lower credit management efficiency in real estate investment trusts in Kenya.

\section{Conclusion and Recommendations}

\subsection{Conclusion}

Based on the research findings, the study evidenced that credit managers in real estate investment trusts are riskaverse in majority. 
The study observed significant variations in bad debt to sales ratio, day's sales in account receivable ratio and default rate over the financial periods covered, among real estate investment trusts in Kenya. The study also found risk taking credit managers to be associated with lower credit management efficiency in real estate investment trusts in Kenya. This implies that the individual risk behavior of credit managers have had an impact on the prevalence or mitigation of customers' defaults and poor debt collection in real estate investment trusts in Kenya.

\subsection{Implications for practice}

The study recommends credit managers working in real estate investment trusts to keep credit risk at minimum when extending credit to clients. This will ensure that business continuity and stability. The study also recommends the implementation of sound credit operations within the firm aimed at mitigating events of customer defaults and enhancing debt collections. Most importantly, firms should critically consider elements such as prior work experience, academic credentials and professional qualifications of candidates during the recruitment of credit managers. Candidates to credit management positions should also have demonstrated a sufficient knowledge and good understanding of the industry and risk inherent in daily activities.

\subsection{Recommendations for Further Study}

The study recommends more research in other financial institutions and a comparative study of the same between the real estate investment trusts and other financial institutions.

Table 1: Attitude to risk of credit managers

\begin{tabular}{lc}
\hline Statement & Factor loading \\
\hline 1. & .973 \\
2. & .972 \\
3. & .693 \\
4. & .519 \\
5. & .394 \\
6. & .362 \\
\hline
\end{tabular}

Table 2: Distribution of efficiency of credit management ratios

\begin{tabular}{|c|c|c|c|c|c|}
\hline Variable & Minimum & Median & Mean & Maximum & STD \\
\hline DR (\%) & 1 & 60.53 & 54.79 & 96 & 26.16 \\
\hline BDS (\%) & 1 & 35 & 46.60 & 100 & 37.49 \\
\hline DSR & 16 & 340 & 408.21 & 1430 & 326.8 \\
\hline
\end{tabular}

\section{Variable Definition}

DR: Default rate,

BDS: Bad debt to sales ratio

DSR: Day's sales in account receivable ratio

Table 3: Correlation analysis

\begin{tabular}{|l|l|l|l|l|}
\hline & BSR & DSR & DR & ATTRISK \\
\hline BSR & 1 & $.793^{* *}$ & $.415^{*}$ & $\mathbf{. 3 2 5}^{*}$ \\
\hline & &.$(000)$ &.$(015)$ &.$(050)$ \\
\hline DSR & & 1 & $.433^{*}$ & $\mathbf{. 4 0 5}^{* *}$ \\
\hline & & &.$(015)$ & $(.009)$ \\
\hline DR & & & 1 & $\mathbf{. 3 5 5}^{*}$ \\
\hline & & & & $(.025)$ \\
\hline ATTR & & & & 1 \\
\hline
\end{tabular}

"P-values in brackets" is indicated as; ${ }^{* * *}$ for $1 \%$ significance level, ${ }^{* *}$ for $5 \%$ significance level, and $*$ for $10 \%$ significance level"

\section{Variable Definition}

DR: Bad debt to sales ratio 
BDS: Day's sales in account ratio

DR: Default ratio

ATTRISK: Attitude to risk of credit managers

Table 4: Regression analysis

\begin{tabular}{|c|c|c|c|}
\hline Variable & DV = BSR & DV= DSR & $\mathrm{DV}=\mathrm{DR}$ \\
\hline Constant & $4.966^{* * *}(4.69)$ & $2.596^{* * * *}(31.2)$ & $2.22^{* * *}(7.22)$ \\
\hline RSKATT & $1.514^{* * * *}(17.30)$ & $0.283^{* * *}(2.17)$ & $0.768^{* * * *}(19.23)$ \\
\hline $\mathrm{AGE}$ & $0.152(1.52)$ & $0.183(1.63)$ & $0.148^{* *}(2.96)$ \\
\hline DEBT & $0.041(0.89)$ & $0.145(1.39)$ & $0.048^{*}(1.99)$ \\
\hline $\mathrm{TA}$ & $-0.296^{* * *}(-3.34)$ & $0.085(0.57)$ & $-0.237^{* * * *}(-0.44)$ \\
\hline PFT & $-0.082(-1.47)$ & $0.067(0.63)$ & $-0.092^{*}(-1.82)$ \\
\hline EXP & $-1.201^{* * * *}(-12.92)$ & $0.502(1.45)$ & $-1.642^{* * * *}(-36.61)$ \\
\hline PQ & $0.4^{* * * *}(4.79)$ & $0.228(0.84)$ & $0.359^{* * * *}(9.39)$ \\
\hline YEAR & Yes & Yes & Yes \\
\hline $\mathrm{N}$ & 36 & 36 & 36 \\
\hline $\operatorname{Adj} R^{2}$ & 0.986 & 0.648 & 0.993 \\
\hline F-value & $113.2^{* * *}(0.000)$ & $4.23^{* * * *}(0.003)$ & $237.38^{* * * *}(0.00)$ \\
\hline
\end{tabular}

t-values in brackets" is indicated as; ${ }^{* * *}$ for $1 \%$ significance level, ${ }^{* *}$ for $5 \%$ significance level, and $*$ for $10 \%$ significance level".

\section{Variable Definition}

RSKATT: Attitude to risk of credit managers

AGE: Company's age

DEBT: Debtor turnover ratio

TA: Total Assets

PFT: Profit

EXP: Work Experience

PQ: Professional Qualification

YEAR: Financial Year

$\mathrm{N}$ : Number of observations

Adj R2: Adjusted $\mathrm{R}^{2}$

F-value: $F$ value (Probability value)

\section{References}

Alshatti. (2015). The Effect of Credit Risk Management on Financial Peformance of the Jordanian Commercial Banks. Journal of Investment Management and Financial Obligations, 1-2.

Bullivant. (2012). Credit Management. (6 ${ }^{\text {th }}$ ed.). Great Britain: Gower Publishing, (Chapter 1).

Cooper, \& Schindler. (2014). Business Research Methods. (12 ${ }^{\text {th }}$ ed.). New York: Mc Graw-Hill Education, (Chapter 3).

Dar, \& Hakeem. (2015). The Influence of Behavioural Factors on Investors Investment Decisions: A conceptual model. International Journal of Research in Economics and Social Sciences, 5(10), 2249-7382.

Dohmen, Falk, Huffman, Sunde, Schupp, \& Wagner. (2011). Individual Risk Attitudes: Measurement, Determinants, and Behavioral Consequences. Journal of the European Economic Association, 9(3), 522550.

Edu, Bassey, \& Okpoho. (2018). Credit Risk Management in Nigerian Banks (2005 - 2015). Research Journal of Finance and Accounting, 9(10), 33-43.

Figlewski. (2016). What Goes into Risk neutral Volatility? Empirical Estimates of Risk Subjective Risk Preferences. [Online] Available: http://dx.doi.org/10.2139/ssrn.2827101 (May 10, 2017)

Grable. (2017). Financial Risk Tolerance. [Online] Available: https://static.arnaudsylvain.fr/2017/03/GrableLyton-1999-Financial-Risk-revisited.pdf (May 10, 2017) 
Greijmans. (2013). Importance of Credit Management. [Online] Available: http://johngreijmans.com/blog/2013/01/07/the-importance-of-credit-management/ (June 12, 2017)

Ingram, \& Thompson. (2012). What's your risk attitude? and how does it affect your company?. [Online] Available: https://hbr.org/2012/06/whats-your-risk-attitude-and-h (June 03, 2017).

Kani. (2017). Credit Risk and Banks Performance: Evidence from WAEMU Countries. Journal of Economics and Finance, 8(1), 2321-5925.

Kolakowski. (2017). Risk Aversion. [Online] Available: https://www.thebalance.com/risk-aversion-1287403

Kusev, Purser, Heilman, Cooke, Schaik, \& Baranova. (2017). Understanding Risky Behavior: The Influence of Cognitive, Emotional and Hormonal Factors on Decision-Making under Risk. Journal of Experimental Psychology.

Mercadante. (2012). Risk Tolerance and How It Affects Your Investment Strategy. [Online] Available: http://www.moolanomy.com/6085/risk-tolerance-its-affect-investing-kmercadante/

Moss. (2013). Agricultural Finance. (1st ed.) New York: Routledge, (Chapter 1).

Murithi, Waweru, \& Muruti. (2016). Effect of Credit Risk on Financial Performance of Commercial. Journal of Economics and Finance, 4(7), 72-83.

Mutua. (2015). Effect of Mitigating Credit risk on perfromance of commercial banks in Kenya: A case of Chuka Town. European Journal of Business and Social Sciences, 7(4), 113-125.

Paraschiv, \& Shyti. (2017). Decision Making in Behavioral Stratgey. ( $1^{\text {st }}$ ed). New York: T.K Das, (Chapter 2)

Payne. (2015). The changing capabilities of credit management. [Online] Available:

https://www.graydon.co.uk/blog/changing-capabilities-credit-management (June 12, 2017)

Perez. (2014). The 8 types of bank risks. [Online] Available: https://marketrealist.com/2014/09/must-know-8types-bank-risks (June 06, 2017)

Satti. (2013). Investor Knowledge, Risk aversion and investment decision. Journal of actual problems in economics, 146(8), 380-389.

Simkovic. (2016). What Can We Learn from Credit Markets. (Proceedings of the 93rd Annual Meeting of the American Law Institute ed.). New York: American Law Institute.

Simkovic, \& Kaminetzky. (2010). Leveraged buyout bankruptcies, the problem of hindsight bias and the credit default swap solution. [Online] Available: . https://papers.ssrn.com /sol3/papers.cfm?ab stract_id=163 2084 (March 16, 2017)

Weber, Blais, \& Betz. (2002, August 1). A Domain-specific Risk-attitude Scale:Measuring Risk Perceptions and Risk Behaviors. Journal of Behavioral Decision Making, 263-290.

Yang, Wenchun, \& Jiaojiao. (2017). Credit Risk Management Framework for Rural Commercial Banks in China. Journal of Financial Risk Management(6), 48-65.

Zinn. (2017). The Meaning of Risk- Taking: key Concepts and Dimensions. Journal of risk and research. 